\title{
ポリイミド被覆を有する石英製キャピラリの引張強度評価*
}

\author{
荒 井 雅 嗣*1, 鵜 飼 征 一*2
}

\section{Evaluation of Tensile Strength on Polyimide covered Silica Capillary Tubing}

\author{
Masatsugu $\mathrm{ARAI}^{* 3}$ and Seiichi UGAI \\ ${ }^{* 3}$ Mechanical Engineering Research Laboratory Hitachi, Ltd., \\ 832-2 Horiguchi, Hitachinaka-shi, Ibaraki, 312-0034 Japan
}

\begin{abstract}
We evaluated the distribution of tensile strength in polyimide covered silica capillary tubing. We also investigated the effect of the polyimide covering on the tensile strength and analyzed the effect of the initial non-penetrated crack length on the crack propagation by using FEM. The diameter of silica capillary tubing was $150 \mu \mathrm{m}$. The surface of the silica capillary tubing was covered with a $12^{-}$ $\mu \mathrm{m}$-thickness of polyimide. The length of the tensile specimens was $400 \mathrm{~mm}$. The relation between the tensile strength of silica capillary tubing and the fracture probalility was distributed into a strong and a weak group. The tensile strength distribution in the strong group was the original strength distribution caused by manufacturing deviation, and that of the weak group resulted from microcracks introduced during or after the specimen manufacturing process. We can predict the strength of the silica capillary tubing using the strength of the optical fibers, because the strength properties of the silica capillary tubing with the polyimide covering were the same as the static strength properties of the optical fibers. We found that the polyimide covering did not improve the tensile strength of the silica capillary tubing, but it was effective as an overcoat. Using FEM analysis, we found that the non-penetrated crack in polyimide covering did not reach the quartz surface during handling, and crack propagation was restrained near the interface because Young's modulus of the polyimide was smaller than that of quartz. When applying silica capillary tubing, we recommend that more attention should be paid to the micro-crack formation on the surface of the quartz than to the crack growth in the polyimide covering.
\end{abstract}

Key Words : Silica Capillary Tubing, Polyimide, Tensile Strength, Fracture Probability, Crack Growth, Stress Intensity Factor

\section{1. 緒論}

近年，石英製の極細線の光ファイバやキャピラリ は, 光学特性や加工精度が良いことから, 光通信分野 のみならず精密機器等の分野でも適用されるようにな ってきた. たとえば, DNA (Deoxyribonucleic Acid, デオキシリボ核酸）解析装置では，石英製のキャピラ リを分析用サンプルの流路として用いている(1). 光フ アイバやキャピラリをこのような精密機器等に用いる には, 強度特性を十分に把握することが必要不可欠で ある. ところで, 光通信分野では, 光ファイバの静的 強度, 疲労・劣化に関する数多くの研究成果が報告® ↔されている. 例えば, 直径 $125 \mu \mathrm{m}$ の光ファイバの 強度は, 理論強度に近い約 $5 \mathrm{GPa}$ と極めて高いことが 報告(2)されている. 稲垣(引らによれば, 破壊力学的観 点より, 光ファイバの強度が理論強度に近いので, 光

* 原稿受付 2004 年 11 月 4 日.

*1 正員, (株) 日立製作所機械研究所(焉312-0034 ひたちなか 市堀口 832-2).

*2 (株) 日立ハイテクノロジーズ(ङ312-8504 ひたちなか市市 毛 882).

E-mail : masatusgu.arai.gj@hitachi.com
ファイバの表面に $1 \mu \mathrm{m}$ の傷が形成されると, 強度は 0.4GPa と著しく低下することが報告されている.さ らには光ファイバの強度を保証するための強度スクリ 一ニングの方法や製造中の強度バラツキの低减法に関 して報告(2)されている. したがって, 精密機器等の 分野で光ファイバやキャピラリを適用するにあたって は，これまでの研究知見ひ㐫を参考にできると言える. しかしながら, 光ファイバやキャピラリを構造材料と して適用すると, 製品毎に光通信分野とは異なる強度 信頼性に関する検討が必要になる.たとえば，キャピ ラリを任意の長さに短く裁断して用いるため, 裁断時 や組み立て中に生じた石英表面のマイクロクラックの 形成により, 強度低下を引き起こす可能性がある. ま た, 機能向上の点からキャピラリ表面の被覆を剥がす 場合もあり, 被覆の除去に伴う強度低下も懸念される. 本報告では； キャピラリを用いる際の強度設計指針 を得ることを目的として, ポリイミド被覆した外径 $150 \mu \mathrm{m}$, 内径 $50 \mu \mathrm{m}$ のキャピラリを長さ $400 \mathrm{~mm}$ に裁 断した場合の張強度のバラツキ, ポリイミド被覆の 一部を加熱して脆くした場合の強度低下について検討 
した. さらに, ハンドリング中のキャピラリは長尺の ため, 曲げ変形を生じることが多い, そのため, ポリ イミト被覆に末貫通のき裂が形成されている場合には, 未貫通のき裂が曲げ変形によって進展し，石英表面を 露出することが懸念される. そこで, ポリイミド被覆 に未貫通のき裂が形成されている場合のき裂進展につ いて検討した.

\section{2. キャピラリの引張強度}

$2 \cdot 1$ 試験片形状と弓張試験力法 図 1 に実験に 供したキャピラリの形状を示す．キャピラリは, 石英 製の外径 $150 \mathrm{~m}$, 内径 50 m の円筒状で, 表面を厚さ $12 \mu \mathrm{m}$ のポリイミドで被覆されたものである.このキ ヤピラリは，光ファイバと同様な工程で製作され，引 き抜き, ポリイミド被覆後, 強度スクリーニングの工 程を経たものである. 図 2 に引張試験片の形状及び引 張試験法を示す. 引張試験片は, 長さ $400 \mathrm{~mm}$ で,そ の両端に石英製ガイド $(\phi 1.8 \mathrm{~mm} \times 6.5 \mathrm{~mm})$ を 2 液混合熱 硬化型のエポキシ接着剤で固定したものである. なお, 製造ロットの影響を把握するために, 引張試験片を 3 種類 $(\mathrm{A}, \mathrm{B}, \mathrm{C})$ のロットから各 18 本づつ採取し, 実験 に供した. 引張試験治具は, 光ファイバでの研究事例 (2を参考に，キャピラリ両端の石英製ガイドのみが固 定できるスリットを設けた構造とした.これにより引 張試験治具とキャピラリは直接接触せず，キャピラリ に単軸の引張荷重のみを負荷することができる. また, 上部には荷重測定用のロードセルを設置した. 引張試 験は油圧サーボ式試験機を用いてクロスヘッド速度 $5 \mathrm{~mm} / \mathrm{min}$ 一定として, 室温大気中で行った. なお, 引張試験治具に取り付け後のキャピラリには, 手動で $1 \mathrm{~N}$ の張力を負荷させて, キャピラリにねじれが発生 しないことを確認した後, $1 \mathrm{~N}$ の張力を負荷させた状 態から引張試験を開始した. 公称の引張応力は荷重を 公称の断面積で除して求めた. さらに，(1)式に示寸対 称ランク法をを用いて, 引張強度の低い順から数えた 第 $\mathrm{i}$ 番目の引張試験片の累積破壊確率 $\boldsymbol{F}$ (\%)を求めた.

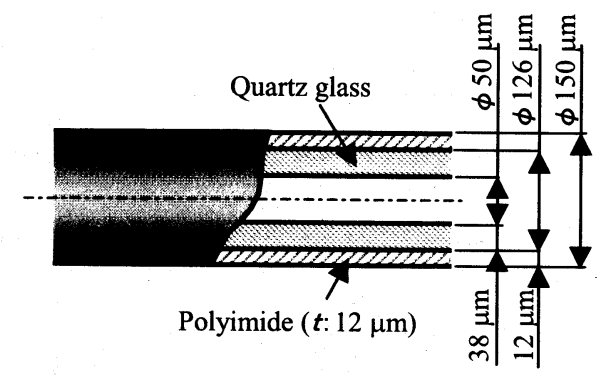

Fig. 1 Shape of silica capillary tubing

$$
F=\frac{i-0.5}{n} \times 100
$$

\section{ここで, $n:$ 試料の数}

本研究では，破壊起点及ひ破断面の様相を確認する ために, 引張試験後の一部の試験片について走査型電 子顕微鏡(SEM)を用いて破面観察を実施した。

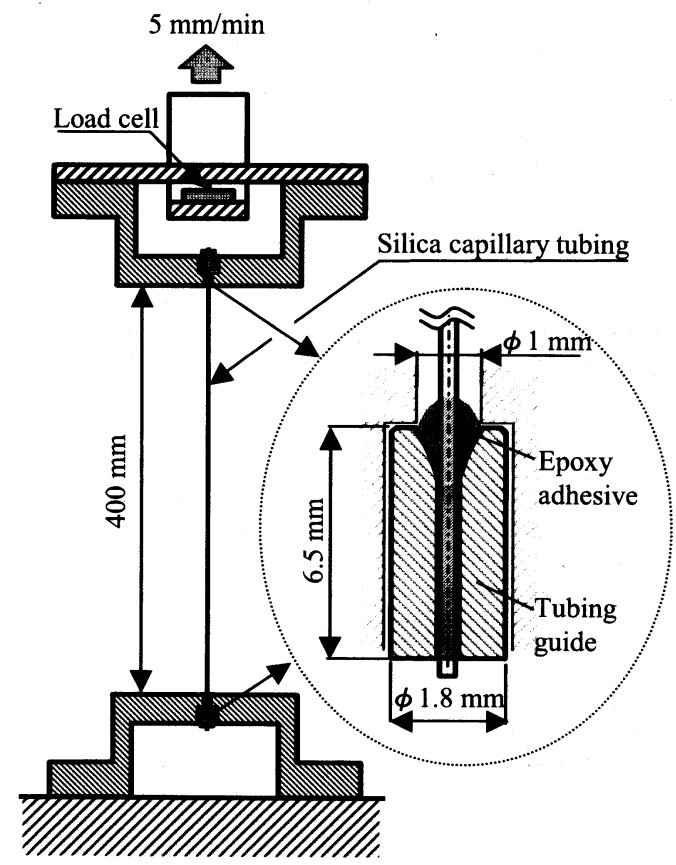

Fig. 2 Tensile experiment method

$2 \cdot 2$ キャピラリの引張強度特性 初めにキャピ ラリに負荷する荷重を増减させ引張試験法の妥当性を 確認した. 図 3 に引張試験時の経過時間とキャピラリ に負荷される荷重の関係, 図4にひずみと応力の関係 で再プロットした結果を示す. 図4に示すひずみは, 予め測定したキャピ.ラリの長さと試験機に取り付けた 変位計の值から算出した值である.ひずみ量の増加に 伴い応力は若干ではあるが下に凸の曲線となっている. また, 荷重を増堿する荷重変化を繰り返しても, ひず みと荷重の関係には変化が認められず, 再現性が良い ことがわかる. ひずみと応力の関係が直線にならない 理由については明確に分からないが，再現性が良いこ とから治具や接着部の伸び等の影響がなく, 良好な引 張試験が行われていると考えられる. 以降の試験は, 破壊するまで荷重を負荷する一般的な引張詿験とした. ところで, ハンドリング中のキャピラリに生じる応力 は, 長尺のため, 曲げ応力であることが多い. そこで, 引镸強度のデータをまとめるにあたっては, (2)式を用 いて曲げ半径と引張応力 $\sigma_{b}$ の関係を求め, その值も 
併記した。

$$
\sigma_{b}=E \frac{D}{2 R}
$$

ここで, $E:$ ヤング率(70GPa), $D:$ キャピラリの 外径 $(0.126 \mathrm{~mm}), R:$ 曲げ半径 $(\mathrm{mm})$

図 5 にキャピラリの引張強度と破壊確率の関係をワ イブル確率紙にプロットした結果を示す．同図の横軸 には, 曲げ半径と引張強度との相関も併記している. 同図に示すように, ロット間の強度バラツキは認めら れず，キャピラリの引張強度と破壊確率との関係は， 大きく分けて 2 つグループ (低強度群 $\mathrm{G} 1$, 高強度群 G22に分布していることが分かる. 高強度群 $\mathrm{G} 2$ に分布 している試験片の強度データは $2500 \sim 4500 \mathrm{MPa}$ の範 囲に分布するが，一方，低強度群 $\mathrm{G} 1$ の強度データは 160〜2500MPa と強度バラツキも大きい. 引張強度と 曲げ半径との相関を見ると， A,B,C のロット中で最も 強度の小さい試験片では, 曲げ半径が 7 30mm で折 損することになる. したがって, ハンドリング中の折 損が容易に発生することが示唆され，低強度群のキャ ピラリは製品に適用することができないと考えられる. ここで, 本結果と光ファイバでの強度評価事例を 比較する. 光ファイバ (被覆厚さ $10 \mathrm{um}$, 長さ $200 \mathrm{~mm}$ ) の引張強度と破壊確率の関係に拄いても, 高強度群と

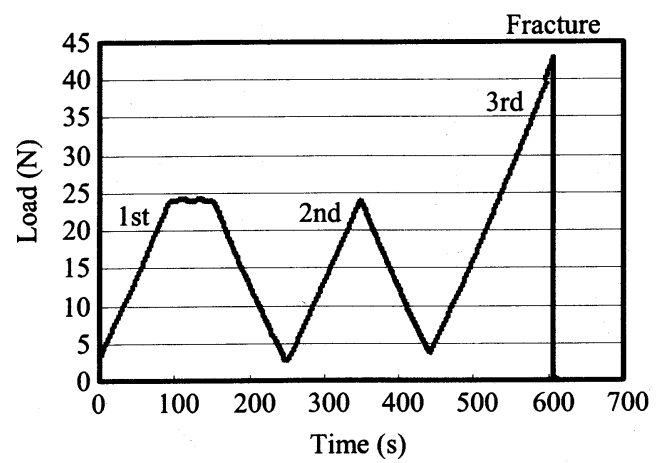

Fig. 3 Tensile test of silica capillary tubing results

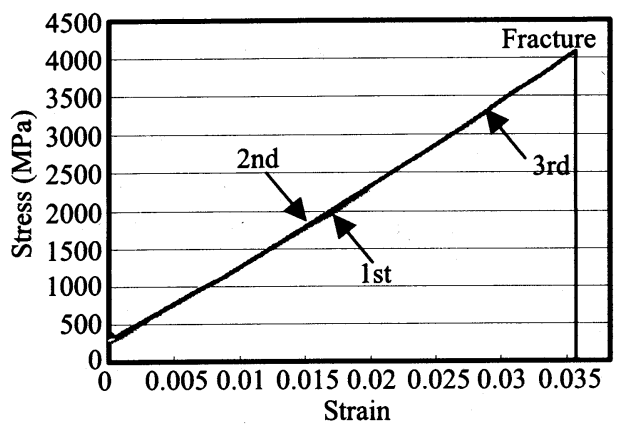

Fig. 4 Relationship between stress and strain on silica capillary tubing

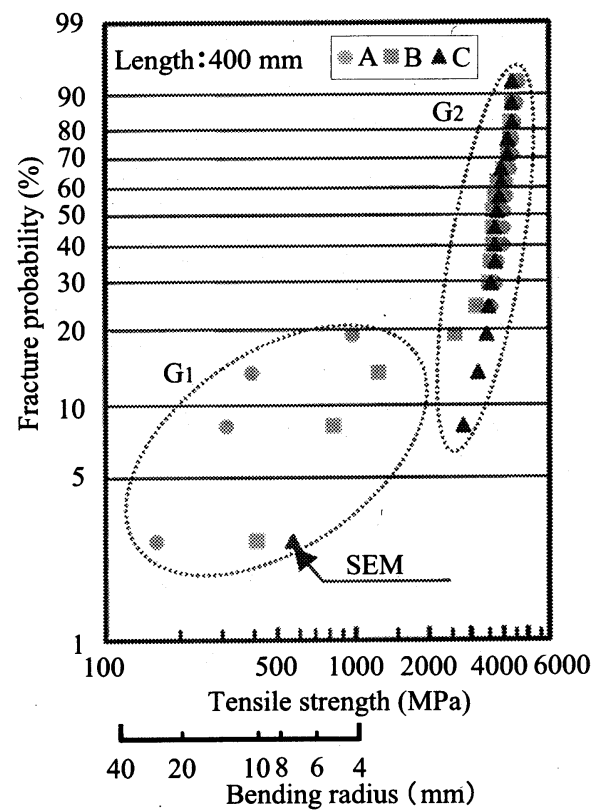

Fig. 5 Relationship between fracture probability and tensile strength of silica capillary tubing

破壊確率 10２0\%以下に分布する低強度群に分布し ている. したがって, これらを考慮すると, 光ファイ バとは断面形状が異なるが，ポリイミト被覆したキャ ピラリの強度特性は光ファイバと同様であり, 光ファ イバの水分による強度劣化や疲労強度の特性，さらに, 強度劣化に及ぼす被覆材の厚さ，製造中のコンタミの 影響等の知見を参考に，キャピラリの強度向上や疲労 強度の推定ができると考えられるひい。

次に，破断した試験片の破断面観察を実施した. 図 6に, 図 5 中の SEM と記述した低強度群 G1 に属する 試験片の SEM 写真を示す，破断面には，破壊起点よ り破壊が進展した様相が認められる. また. 起点近傍 のポリイミド被覆の断面は, 他のポリイミド被覆の断 面とは様相が異なり，起点近傍のみがロ状になり，傷 が形成された様相が認められる。 一方, 引張試験後の 高強度群の試験片は，粉々に破壊しており起点を特定 することは不可能であった. なお, 低強度群に属する 試験片8本のうち 4 本について破断面を観察したが, 図 6 と同様に破壊起点が認められた。本試験片は，製 造後に強度スクリーニング(プルーフテスト(3)の工程 を通過したキャピラリであることから，試験片の製作 中又は試験準備中に強度が低下したと考えられる.ま た, 高強度群の強度が $2500 \sim 4000 \mathrm{MPa}$ と理論強度に 近いこと，さらに石英の破壊勒性が非常に小さい $\left(3 \mathrm{MPa} \cdot \mathrm{m}^{12}\right.$ (5) $)$ こを考慮すると，低応力で破断した 試験片は, 試験片の製作中又は試験準備中にポリイミ 
ト被覆を貫いて形成された石英表面の傷(マイクロク ラック)を起点として破壊に至ったと判断される.

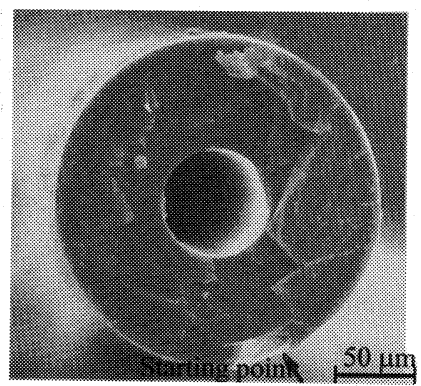

Fig. 6 SEM fracture surface after tensile experiment

\section{3. ポリイミド被夏の効果}

$3 \cdot 1$ 被覆の加熱方法引張強度に及ぼすポリイ ミド被覆の効果を検討するために, ポリイミド被覆を 加熱させたキャピラリを用いて, 引張試験を行った. 試験片は，ロット A,B,C とは異なるキャピラリを用い て, 中央部の長さ $10 \mathrm{~mm}$ にわたって, $450^{\circ} \mathrm{C}$ の気中 で 30min 加熱して脆くさせたものである. なお，キャ

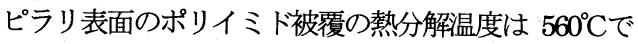
ある. 引張試験は，ポリイミド被覆を加熱していない キャピラリと同様に; 油圧サーボ式試験機を用いて室 温大気中で行った.

$3 \cdot 2$ き裂先端の応力解析方法 キャピラリは長 尺のため, ハンドリング中に曲げ変形を生じることが 多い. そこで, 未貫通のき裂を有するキャピラリに曲 げ変形が生じた場合のき裂進展を推則するために, 有 限要素法(FEM)による応力拡大係数の解析を行った. 解析では, ポリイミド被覆のき裂先端は, キャピラリ の円筒状の上面であるので, 等価な剛性を有する板の 表面に形成されたき裂とほぼ同等な応力場と考えた.

図 7 に FEM 解析モデル, 表 1 に FEM 解析で用いた 物性を示す. FEM 解析モデルは, 2 次元の平面ひず みモデルと簡略化してキャピラリと同一な断面剛性を 有する長さ $2 \mathrm{~mm}$, 厚さ $125 \mu \mathrm{m}$, 幅 $150 \mathrm{\mu m}$ の板と仮 定した. また，ポリイミドのヤング率は石英より極め て小さく, キャピラリの変形には影響しないと考えら れる. そこで, ポリイミド被覆の厚さは, 実形状と同 じ厚さである $12 \mu \mathrm{m}$ とし, ポリイミト被覆と石英との 界面には残留ひずみは生じていないものとした. また, ポリイミド被覆には表面と垂直に未貫通の長さ 2 〜 $11 \mu \mathrm{m}$ のき裂が形成していると仮定した. 要素寸法は き裂先端に近くなるに伴って小さくし, 最小 $0.05 \mu \mathrm{m}$ とした. 荷重 $F$ はき裂長さによらず，一定值を右端 のY方向に加えた.

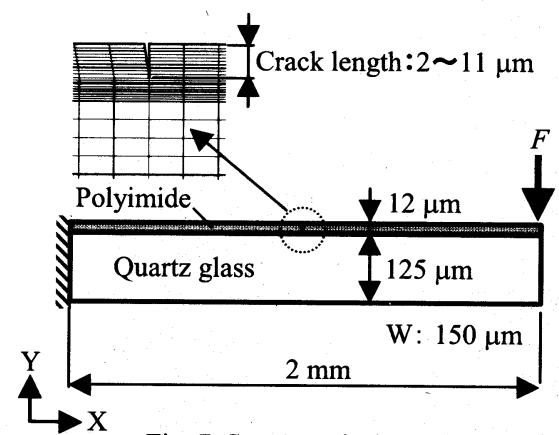

Fig. 7 Stress analysis model

Table 1 Mechanical properties of silica capillary tubing

\begin{tabular}{|c|c|c|}
\hline Materials & $\begin{array}{l}\text { Young's } \\
\text { modulus } \\
(\mathrm{GPa})\end{array}$ & $\begin{array}{l}\text { Poisson's } \\
\text { ratio }\end{array}$ \\
\hline Quartz glass & 70 & 0.23 \\
\hline Polyimide & 2.6 & 0.35 \\
\hline
\end{tabular}

$3 \cdot 3$ ポリイミド被覆の効果とき裂進展 図 8 に, 加熱してポリイミド被覆を脆くした試験片の引張強度 と破壊確率の関係をワイブル確率紙にプロットした結 果を示す. 同図には, 図5に示したキャピラリの結果 も併記してある. 同図に示すように, キャピラリの引 張強度は低強度群に属するキャピラリの数は少ないも のの 2 つグループに分布していることが分かる. ま た, 低強度群に属したキャピラリは, 加熱していない 部分で破壊した. この結果より， $450^{\circ} \mathrm{C}$ に加熱したこ とによるキャピラリの強度低下はなく, 加熱無しのキ ヤピラリと同じ強度を有すると考えられる. また, 口 ット間での強度特性の差もないと考えている. したが って, ポリイミド被覆を加熱(脆く)しても強度低下が 認められないことから, ポリイミド被覆は強度部材で は無いと考えられる. 光ファイバでの研究事例(た よれば, 被覆を施していない光ファイバの強度は被覆 有りのものより 1 析低くなり, かつその強度分布のバ ラツキも小さくなることが報告されている. すなわち, キャピラリ表面にマイクロクラックが安定して形成さ れ，その結果強度バラツキも小さくなっていると考え る. また, 光ファイバではマイクロクラック形成の要 因として, 製作中の炉内のダストの影響についても述 べられている. したがって, 本実験結果と光ファイバ での事例より, ポリイミド被覆は, 強度低下の要因と なる石英表面のマイクロクラック形成を防止するため の保護膜としての効果が大きいと考えられる.

以上の結果より, ポリイミド被覆は強度部材ではな く保護膜であると判断できる. したがって, ポリイミ 
ト被覆の表面に形成された未貫通のき裂が進展して, 石英が露出すると保護膜としての効果が低下すること が䀣念される. そこで, ポリイミド被覆に未貫通のき 裂が生じている場合のき裂進展について考察した。

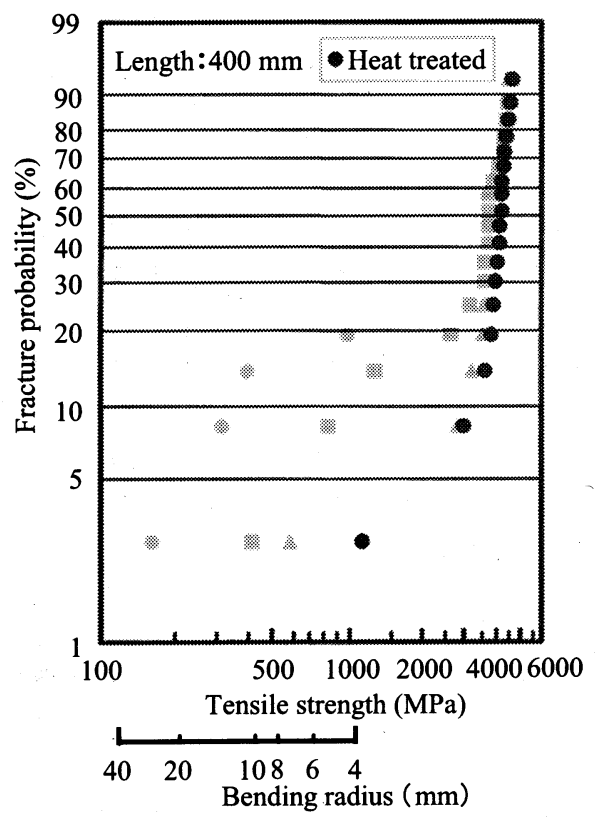

Fig. 8 Relationship between fracture probability and tensile strength of heat treated silica capillary tubing

き裂先端の応力は理論上無限大(文)であるので, き 裂先端の応力場を(3)式に示す関係式(の施を用いて評 価する.

$$
\sigma=\frac{K}{(2 \pi r)^{\lambda}}
$$

ここで, $K$ : 応力拡大係数, $r$ : 応力特異点からの距 離, $\lambda:$ 特異性の指数 (0.5)

図9に解析の一例を示す，同図はポリイミド被覆に 長さ $3 \mu \mathrm{m}$ のき裂を有している場合の解析例で, 横軸 にき裂先端からの距離, 実線は特異性の指数入を理論 值の 0.5 とした直線である. 図より, き裂先端近傍の 応力分布は, 特異性の指数皇 0.5 とした直線と一致 していることがわかる. 図 10 に, ポリイミド被覆の き裂長さと特異性の指数の関係を示す. 同図に示す特 異性の指数は, 解析結果と(3)式を用いて最小 2 乗近似 で求めたものである. 同図に示すように, 特異性の指 数はき裂長さが $2 \sim 10 \mathrm{um}$ の範囲では理論值とほぼ等 しく $\lambda=0.5$ であるが, き裂長さが. $11 \mu \mathrm{m}$ と長い場合 は特異性の指数が小さいことが分かる. そこで以下は, 2〜10um の範囲でき裂が存在していると仮定して,
き裂長さと応力拡大係数の関係について考察した. 図 11 にポリイミド被覆内のき裂長さと応力拡大係数の 関係を示す. 同図は(3)式に示した特異性の指数を 0.5 として解析值より算出した結果を基に, 最大の応力拡 大係数を 1 としてプロットしたものである. 同図に示 すように, き裂が長くなるに伴って応力拡大係数は若 干増加するが, き裂長さが 10um に達すると応力拡大 係数は低下寸ることがわかる. き裂長さが $10 \mathrm{um}$ 以上 の界面近傍の応力拡大係数については, き裂先端の応 力拡大係数とは異なった取り扱いや解析が必要( ある. そこで, 文献田《1)を基に応力拡大係数を推定す ると, 同図に示寸点線のように, 界面に近づくに伴っ て低下寸ると考えられる. これは, ポリイミドのヤン グ率が石英に比べ極めて小さく, き裂がポリイミド被 覆と石英の界面近傍で拘束されるためで，このような 現象はクラックアレスト効果(11)と呼ばれている.し たがって, この効果により, ポリイミト被覆に生じた き裂は, ポリイミト被覆と石英との界面近傍で停止, または進展する方向が変化すると考えられる. したが

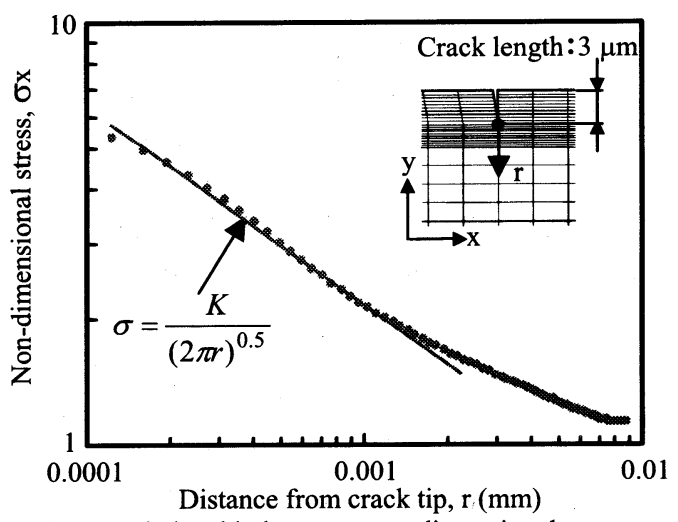

Fig. 9 Relationship between non-dimensional stress and distance from crack tip (Crack length $3 \mu \mathrm{m}$ )

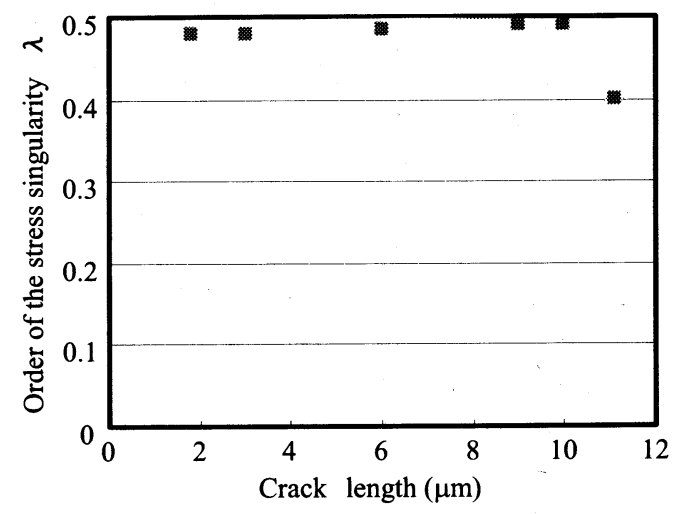

Fig. 10 Relationship between order of the stress singularity and crack length 


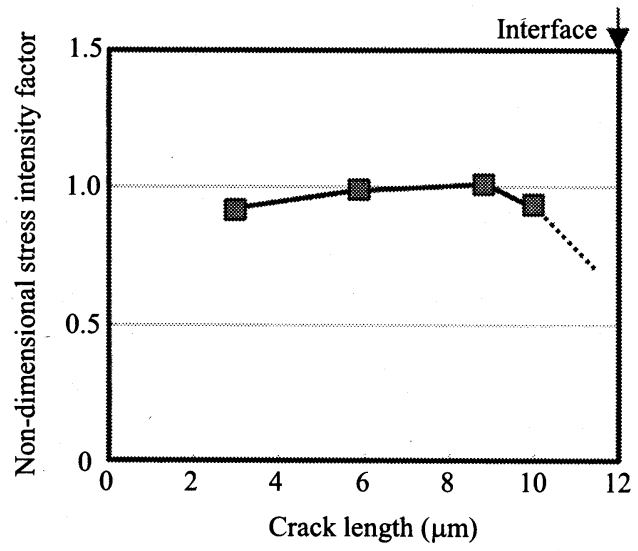

Fig. 11 Relationship between non-dimensional stress intensity factor and crack length

って，ポリイミド被覆の未貫通のき裂が，ハンドリン グ中の曲げ変形の繰り返しによって進展して石英表面 に達し，さらに石英が露出することでマイクロクラッ クを形成して，強度低下を引き起こすとは考えにくい．

\section{4. 強度設計に関する提量}

キャピラリの引張強度と破壊確率との関係は, 大 きく分けて $2 つ の$ 領域に分布している.これは, キ ヤピラリ自身がもつ強度バラツキと, 試験片の製作 中又は試験準備中に生じた石英表面のマイクロクラ ックを起因とした強度低下のためと考えられる．ま た, ポリイミド被覆は, キャピラリの強度向上には 寄与しておらず, 石英表面のマイクロクラック形成 を防止するための保護膜としての効果が大きい，ポ リイミド被覆に生じている未貫通のき裂は, き裂が 界面近傍で拘束されるので, き裂が進展して石英表 面を露出し，強度低下を引き起こすとは考えにくい． これより, 精密機器等の組み立て現場では, ポリイ ミド被覆の未貫通のき裂進展に配慮(例えば, ハンド リング時の曲げ変形を抑制すること)するよりも，ポ リイミド被覆を貫いて形成する傷をいかに抑制する べきかに配慮するべきと考える.すすなわち, 各製品 に組み込まれているキャピラリの強度は, 組み立て 前の工程で低下している可能性があり, 試験片レベ ルの強度值や強度バラツキを用いて設計することが 難しいと考えられる. たとえば, 製造工程が増える と, 石英表面のマイクロクラックを形成する確率も 高くなり, 低強度で折損するキャピラリの比率が多 くなると考えられる.

以上を踏まえると, 強度信頼性を確保するには, 製造工程中のマイクロクラックの発生源となるキャ ピラリの裁断破片や, 生産現場の異物を减らすこと
が最も重要であると考える．例えば，キャピラリを 裁断する際には, 裁断破片を回収する装置を設ける 等の工夫が必要である. さらには, 石英表面のマイ クロクラックが形成されにくい製造工程や，ポリイ ミド被覆を厚肉化して石英表面のマイクロクラック を形成しにくくする等の工夫も必要であると考える.

\section{5. 結就}

直径 $150 \mu \mathrm{m}$, ポリイミド被覆したキャピラリを長 さ $400 \mathrm{~mm}$ に裁断した試験片の引張強度のバラツキ, ポリイミト被覆の一部を加熱して除去した場合の強度 劣化，さらにポリイミト被覆に未貫通のき裂が形成さ れている場合のき裂進展について検討し, 以下の結論 を得た。

(1)キャピラリの引張強度は, キャピラリの本来の 強度を有する高強度群 $(2500 \sim 4000 \mathrm{MPa})$ と, 試 験片を製作する際や引張試験準備中に生じた石 英表面のマイクロクラックによって強度が低下 した低強度群 $(600 \sim 2500 \mathrm{MPa}$ に分布している.

（2）ポリイミド被覆の一部を $450^{\circ} \mathrm{C} \times 30 \mathrm{~min}$ に加熱 してポリイミドを脆くしても, 強度低下は認め られない。

(3)ポリイミド被覆は, キャピラリの強度向上に寄 与しておらず, 石英表面のマイクロクラックの 形成を防止するための保護膜としての効果が大 きい.

（4）ポリイミド被覆の未貫通のき裂は, き裂が進展 して石英表面を露出させ強度低下を引き起こす とは考えにくいので，キャピラリを様々な製品 で適用するにあたっては，ポリイミド被覆のき 裂進展に配慮するよりも，石英のマイクロクラ ック形成の抑制に留意するべきである.

\section{6. 参考文献}

(1)村松正明，那波宏，DNA マイクロアレイと最新 PCR 法, (2000)，115，秀潤社

(2)稲田浩一, 光ファイバの話,(1995), 128-135, 裳華房. (3)稲垣伸夫, NEWGLASS, NNo.3，(1986), 36-39 (4)MJohn and Vishal Padiyar, ProcSPIE, 4215, 2001,5369. (5)萩原芳彦, 鈴木秀人，破壊力学，(2000), 75, オ一八社 (6)小林英男，破壊力学，(1995)，62，共立出版 (7)井上忠信, 久保司朗，材料，48-4，(1999)，365-375 (8)結城良治, 界面の力学, (1993), 85, 培風館 (9)山崎淳一, 結城良治, 北川英夫, 機論, 52-473，A(1986), 108-116

(10)結城良治，Cho 相鳳，松本敏郎，機論，53-492，A(1987), $1581-1589$

（11)山崎淳一，北川英夫，材料，29323，(1980)，801-806 